\title{
Diversity, threats and conservation of native bees in the Neotropics*
}

\author{
Breno M. Freitas ${ }^{1}$, Vera Lúcia IMPERATRIZ-FonseCA ${ }^{2}$, Luis M. MEdinA ${ }^{3}$, \\ Astrid de Matos Peixoto KLEINERT ${ }^{2}$, Leonardo GALETTO $^{4}$, Guiomar NATES-PARRA ${ }^{5}$, \\ J. Javier G. QUEZADA-EUÁN ${ }^{3}$

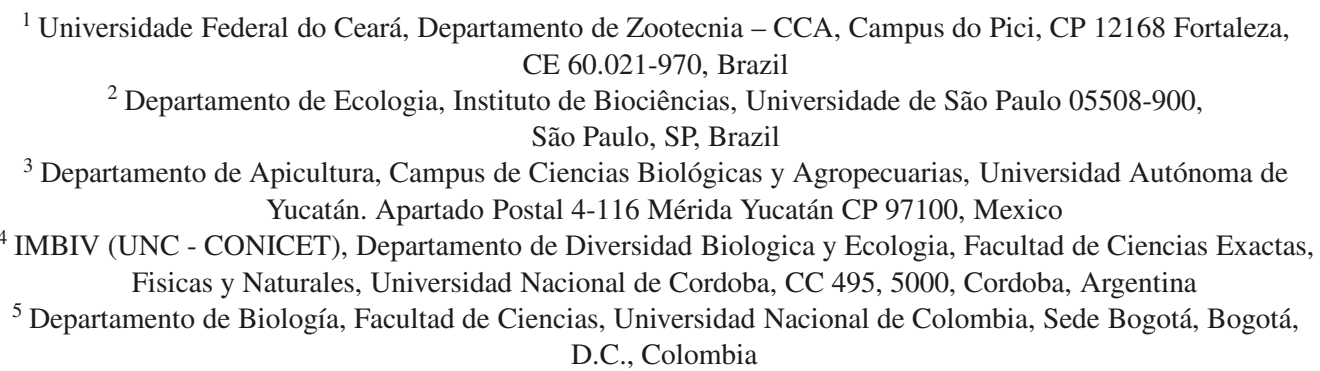

Received 30 October 2008 - Revised 19 December 2008 - Accepted 30 January 2009

\begin{abstract}
The Neotropics bee fauna is very rich with 5000 recognised species, including 33 genera (391 species) of Meliponini, but it is estimated to be at least three fold greater in species richness. Deforestation, agriculture intensification and introduction/spread of exotic competing bee species are considered the main threats to most indigenous species, although other less obvious causes can affect the populations of some bee species locally. Efforts to conserve the native bee fauna include better knowledge of bee richness and diversity (standardized surveys, larger bee collections and appropriate identification of bee species) and of their population dynamics, raising of public and policy makers' awareness, commercial applications of bee products and services such as pollination and preservation of natural habitat.
\end{abstract}

Apoidea / bee biodiversity / Central America / South America / conservation / taxonomy

\section{BEE RICHNESS IN THE NEOTROPICS}

It is well recognized that the Neotropics bears a rich bee fauna (Moure et al., 2007). However, obtaining precise figures of this richness is not easy due to a series of reasons such as the spread of this information in thousands of papers, books, dissertations and thesis; the lack of accurate information on valid names, synonymy, homonymy, misidentifications and

Corresponding author: B.M. Freitas, freitas@ufc.br

* Manuscript editor: Mark Brown nomina nuda; and the existence of many areas/regions poorly sampled from where figures on bee richness are certainly low.

The recent publication of Moure's catalogue (Moure et al., 2007), the most comprehensive work of the Neotropical Apoidea so far, has compiled most information available and presented reliable data on numbers and the geographic distribution of bee species. The catalogue presents 5000 valid bee species names but estimates an astonishing total number of 15150 bee species in the Neotropics, implying that all data available up to date on bee diversity in the region represents less than a third of actual species richness (Tab. I). 
Table I. Number of Neotropical bee species by country. Numbers in brackets are the estimated total number of species using the equation: $\mathrm{y}=0.2889 \mathrm{x}+1.2108 ; \mathrm{r}^{2}=0.984$, where $\mathrm{y}=$ estimated total number of species.

\begin{tabular}{|c|c|c|c|c|c|c|}
\hline$\overline{\text { Country }}$ & Total & Andreninae & Apinae & Colletinae & Halictinae & Megachilinae \\
\hline Anguilla & 1 & $\overline{-}$ & 1 & - & - & $\overline{-}$ \\
\hline Argentina & 1021 [1183] & 106 & 385 & 139 & 104 & 287 \\
\hline Bahamas & $20[256]$ & - & 6 & 1 & 9 & 4 \\
\hline Barbados & 9 & - & 5 & - & - & 4 \\
\hline Belize & 30 [296] & - & 26 & - & 2 & 2 \\
\hline Bermuda & 2 & - & - & - & 1 & 1 \\
\hline Bolivia & 487 [904] & 1 & 248 & 52 & 75 & 111 \\
\hline Brazil & 1678 [1633] & 82 & 913 & 104 & 251 & 328 \\
\hline Cayman Islands & 1 & - & - & - & - & 1 \\
\hline Chile & 409 [812] & 60 & 83 & 142 & 57 & 67 \\
\hline Colombia & 398 [914] & 9 & 262 & 23 & 64 & 40 \\
\hline Costa Rica & 416 [372] & - & 253 & 21 & 86 & 56 \\
\hline Cuba & 82 [466] & - & 36 & 6 & 23 & 17 \\
\hline Dominica & 16 & - & 9 & - & 3 & 4 \\
\hline Dominican Republic & 27 [367] & - & 10 & 1 & 6 & 10 \\
\hline Ecuador & 305 [611] & - & 194 & 22 & 46 & 43 \\
\hline El Salvador & 59 [288] & - & 42 & 2 & 10 & 5 \\
\hline French Guiana & 163 [439] & - & 135 & 3 & 14 & 11 \\
\hline Grenada & 11 & - & 8 & - & 2 & 1 \\
\hline Guadeloupe & 11 & - & 9 & - & - & 2 \\
\hline Guatemala & 216 [464] & 4 & 142 & 13 & 34 & 23 \\
\hline Guyana & $220[564]$ & - & 160 & 7 & 27 & 26 \\
\hline Haiti & 27 [312] & - & 15 & - & 8 & 4 \\
\hline Honduras & 175 [468] & 10 & 116 & 6 & 19 & 24 \\
\hline Jamaica & 52 [239] & - & 24 & 5 & 10 & 13 \\
\hline Martinique & 5 & - & 3 & - & - & 2 \\
\hline Mexico Neotropical & 916 & 167 & 400 & 63 & 131 & 155 \\
\hline México whole country* & 1800 & & & & & \\
\hline Montserrat & 8 & - & 6 & - & - & 2 \\
\hline Nicaragua & $52[488]$ & 2 & 45 & 1 & 3 & 1 \\
\hline Panama & 390 [417] & 4 & 249 & 18 & 74 & 45 \\
\hline Paraguay & $478[679]$ & 24 & 208 & 42 & 87 & 117 \\
\hline Peru & $592[946]$ & 5 & 319 & 60 & 122 & 86 \\
\hline Puerto Rico & 29 [225] & - & 12 & - & 10 & 7 \\
\hline Saba \& Sint Eustatius & 2 & - & 2 & - & - & - \\
\hline Saint Kitts and Neves Islands & 3 & - & 2 & - & 1 & - \\
\hline Saint Lucia & 2 & - & 2 & - & - & - \\
\hline Saint Martin \& St. Barthelemy & 2 & - & 2 & - & - & - \\
\hline Saint Vincent and the Grenadines & 37 & - & 15 & 1 & 16 & 5 \\
\hline Suriname & 85 [522] & - & 80 & & 1 & 2 \\
\hline Trinidad and Tobago & 77 [192] & - & 57 & 3 & 5 & 12 \\
\hline Uruguay & $74[532]$ & 4 & 41 & 3 & 15 & 11 \\
\hline Venezuela & 232 [857] & 1 & 185 & 15 & 25 & 6 \\
\hline Virgin Islands & 4 & - & 1 & - & 1 & 2 \\
\hline
\end{tabular}

Source: Moure et al. (2007).

* According to Ayala et al. (1996). 


\subsection{Mexico and Central America}

The apifauna of Mexico and Panama is probably the best studied of the countries that form the Mesoamerica region. Unfortunately, data on the bee fauna in other countries of Central America are scarce, and sampling efforts have only recently started in Guatemala (Enriquez et al., 2003).

Mexico is considered to have intermediate bee richness between that of the United States (ca. 4000) and those in countries from Central America (ca. 600) probably as a result of its position in which elements of Neartic, Mesoamerican and Neotropical origins are combined (Tab. I; Ayala et al., 1993). Within México, there are striking differences; the arid and semiarid regions of the north represent some of the richest bee faunas in the world whilst the Yucatan Peninsula and the highlands above $3000 \mathrm{~m}$ seem to be relatively species poor (Ayala et al., 1993). However, these patterns have been considered tentative since most regions apart from the northern border of Mexico with the United States have been scarcely surveyed, so the number of species may well be above 2000. For instance, in the Yucatan Peninsula, a recent study in the biosphere of Sian Ka'an, in the state of Quintana Roo has revealed the presence of 74 bee species (Roubik et al., 1991) and a survey across the state of Yucatan reported 140 species and the first report of Colletidae $(50 \%$ more species than were reported in previous surveys; Contreras-Acosta, 1998).

The most comprehensive reports of the bee richness of Mexico and Central America are those of Ayala et al. (1993), Maes (1993) and Ayala (2006). From these studies, the estimations for the bee fauna of Mexico are of 8 families, 144 genera and ca. 1800 species. Four bee genera and eight subgenera are endemic. The greatest number of species has been found in the following genera: Centris, Deltoptila, Exomalopsis, Mesoxaca, Peponapis and Protoxea. Yet Moure's catalogues (Moure et al., 2007) did not include bee species in Northern states of Mexico, considering them as belonging to the Neartic fauna. From this point of view, Mexico would have 916 bee species of the Neotropical fauna. Here, we present Moure et al.'s (2007) table on the number of Neotropical bee species by country, including also the estimates based on Ayala et al. (1993), Maes (1993) and Ayala (2006) of the whole of Mexico (Tab. I).

\subsection{South America}

Like in many other parts of the world, the apifauna of South America has been understudied. There have been few surveys in most countries and where they do exist, such as in Brazil, Argentina and Colombia, they are not evenly distributed, tending to concentrate in some regions and leaving others uninvestigated. In Brazil, for example, we found 84 surveys carried out in 130 different localities, but 16 out of them were in 25 sites only in the state of São Paulo. In contrast, the North region of Brazil remains unsampled and few surveys have been made in the Central-West region. These two regions together cover approximately $4700000 \mathrm{~km}^{2}$, representing more than $50 \%$ of the Brazilian territory and include important and extensive biomes such as the Amazon rainforest and the tropical wetland of the Pantanal Matogrossense. Presently, Brazil has 1678 valid species names for bees (Moure et al., 2007).

Besides uneven sampling, the lack of a standardized methodology and type of data collected are important constraints to a comparison among surveys, but Silveira et al. (2002) point out that the appropriate identification of bee species is the major limitation. This is why the great majority of studies have solely undertaken general comparisons based on species richness of Apoidea families found within distinct areas of the same biome (e.g. Silveira and Campos, 1995) or among biomes within the same geographic region (e.g. Jamhour and Laroca, 2004), making clear the urgent need of a synthesis of this accumulated knowledge. Some attempts have been made by Pinheiro-Machado et al. (2002), for instance, who reviewed 46 surveys made in Brazil, presenting information related only to species richness of Apoidea families in different biomes. Biesmeijer et al. (2005) synthesized data from eusocial Apidae from 
27 surveys, making a presence/absence matrix to analyze interactions patterns and the influence of factors such as altitude, latitude and habitat. Biesmeijer and Slaa (2006) also compared data from 28 Brazilian bee surveys in order to explain patterns of species richness, niche width and association among taxa of eusocial Apidae. These difficulties bring much discrepancy: in Colombia Nates-Parra (2005) reports approximately 600 identified bee species to the country, but Moure's catalogue (Moure et al., 2007) recognizes only 398 valid names, although estimates around 900 species in Colombia.

The Meliponini tribe (Hymenoptera: Apidae), eusocial bees native to the New World, exhibit remarkable bee richness in the Neotropics. They form perennial colonies, which inhabit most of the tropical Americas, ranging from the lowlands of Mexico to the northwest of Argentina and Montevideo, Uruguay, including some Caribbean islands, from sea level to altitudes up to $4000 \mathrm{~m}$ in the Bolivian Andes (Camargo and Pedro, 2007). According to Camargo and Pedro (2007), there are 33 exclusively Neotropical valid genera of Meliponini, including one recently extinct species and a total of 391 valid species names.

\section{THREATS TO BEES IN THE NEOTROPICS}

There are many threats to native bees in the Neotropics, all directly or indirectly related to human activities such as habitat fragmentation and habitat loss, unsustainable honey hunting, biological invasions, and intensive use of herbicides and pesticides. However, these threats can be pooled into three major categories: deforestation, agriculture intensification and introduction/spread of exotic species

\subsection{Deforestation}

Neotropical ecosystems along with those from Southeast Asia (Oldroyd and Nanork, 2009) are among the most strongly impacted by deforestation. Logging, firewood gathering, charcoal production, clearing for cattle pasture and agriculture expansion are the main causes of deforestation. Removal of native vegetation affects bee populations basically through the loss/change of floral resources and nesting sites (Kremen et al., 2004).

The Amazon rainforest is the largest expanse of forest in the world (5.5 million $\mathrm{km}^{2}$ ) and is located to the north of the South American continent, being shared by 9 countries: Brazil, Bolivia, Ecuador, Peru, Colombia, Venezuela, Suriname, French Guiana and Guiana. Presently, the Amazon rainforest suffers the highest rates of deforestation in the Americas. The largest part of it is located in Brazil $(60 \%)$ and covers almost half of that country. Brazil is also there where deforestation has been most intense; $756 \mathrm{~km}^{2}$ of forest were cleared in August 2008 alone, an area much larger than Singapore $\left(641 \mathrm{~km}^{2}\right)$, for example. From January to August 2008 deforestation in Brazil amounted to $5.681 \mathrm{~km}^{2}$ (INPE, 2008). According to the Brazilian National Institute of Space Research (INPE) and the World Wildlife Fund (WWF), $17.1 \%$ of the Brazilian Amazon rainforest had been cleared to date (WWF, 2008). Fearnside (2008) has identified the reasons for the intense deforestation of Amazonia. Wood extraction, cattle pasture and, more recently, expansion of soybean plantations towards the North of the Brazil are the main causes of deforestation. In other South American countries, clearing of land for agriculture is more prevalent (WWF, 2008).

Like in the Amazon rainforest, the cerrado vegetation of Central Brazil, which includes the tropical wetland of the Pantanal Matogrossense, is being rapidly replaced by grassland and soybean plantations. Recently Morton et al. (2006) and Souza (2006) used satellite images to demonstrate fast cerrado deforestation and the land use after deforestation. The effects on the bee fauna both in the Amazon rainforest as well in the cerrado in a short span of time can only be roughly estimated, but predictions for the future are potentially catastrophic because they cover large areas, including complete river drainage systems and impact global carbon and water cycles, energy balance and climate (Goudie, 2001; WWF, 2008). These are the regions least sampled in Brazilian bee collections and many bee 
Table II. Average amount of forest reduction per year in Mexico and Central America (FAO, 2003).

\begin{tabular}{lcc}
\hline Country & Hectares per year & \% of total forest lost per year \\
\hline Costa Rica & 18000 & $0.73 \%$ \\
El Salvador & 5100 & $1.36 \%$ \\
Guatemala & 54000 & $1.14 \%$ \\
Nicaragua & 99900 & $1.53 \%$ \\
Honduras & 195900 & $2.65 \%$ \\
México & 347600 & $0.50 \%$ \\
\hline
\end{tabular}

species are probably still to be discovered and described. There is the imminent risk of losing bee species before their discovery.

In the Americas, the regions with the second highest tropical deforestation rates are Mexico and Central America which altogether lost an average of $1.3 \%$ (285000 hectares) of its rainforests each year between 2000 and 2003 (FAO, 2003). However, rates of forest lost are substantially different between countries (see Tab. II).

In Mexico for instance, rapid industrialization and uncontrolled population growth over the last few decades have had a strong impact on the country's environment and left less than 10 percent of its original tropical rainforests standing. Today Mexico's rainforests are limited to southeastern regions along the Gulf of Mexico and the southern state of Chiapas. These forests are most threatened by subsistence activities, especially fuel wood collection, land clearance for agriculture and livestock, illegal logging and poaching (Gomez-Pompa and Kaus, 1999).

During the last 30 years, great pressure on natural woodlands has occurred in central and northern Argentina, mainly due to the expansion of crop fields for soybean, leading to high rates of deforestation (Zak et al., 2004; Grau et al., 2005). The Chaco is the second largest dry forest biome in South America and a significant proportion of it was affected by deforestation. For this region, similar declines in abundance and diversity of solitary and social bees were registered in fragmented and nonfragmented landscapes of Tucumán in NW Argentina (Aizen and Feinsinger, 1994, 2003). A different pattern was observed in Chaco woodlands of central Argentina, because no significant differences were registered in the richness of Hymenoptera in fragmented and continuous forest for two consecutive years (Galetto et al., 2007). A common pattern for these two Chaco regions was that feral honeybees (Apis mellifera) were more frequent on small fragments (Aizen and Feinsinger, 1994; Galetto et al., unpubl. data).

In Colombia, a red book of terrestrial invertebrates (Amat et al., 2007) mentions 10 bee species as threatened, including species of Meliponini and the genus Aglae, Eufrisea and Bombus. Habitat loss and fragmentation due to deforestation are the main threats to native bees from the Pacific coast to the Andes, the Colombian Amazon rainforest and the Caribe (Gonzáles and Nates-Parra, 1999; Nates-Parra, 2005; Bonilla-Gómez, 2007). But there are other causes of concern, such as unsustainable honey hunting in the Andes, Amazon, Orinoquia and Caribe that are affecting populations of the stingless bees Melipona favosa and Melipona eburnea (Nates-Parra, 2007) and, particularly, Parapartamona imberbis which is endemic to high mountains of the Colombian Andes that are now being converted for potato crops and cattle breeding areas. Another four Parapartamona species, P. brevipilosa, $P$. caliensis, $P$. vittigera and $P$. zonata are also endangered, although their distribution also covers the Ecuadorian Andes (NatesParra, 2007).

\subsection{Agriculture intensification}

Agriculture expansion and its intensification throughout the Americas have been pointed out as a major threat to bees (Kremen et al., 2002; Silveira, 2004). Besides being one of the three main causes of deforestation 
along with logging and clearance for cattle pasture, large-scale arable agriculture also reduces plant and animal diversity dramatically, diminishing bee nesting and feeding opportunities and kills adult and larval bees by using agrochemicals and by ploughing the soil.

The density of stingless bee nests in the southern state of Yucatan in Mexico was significantly higher in undisturbed areas compared to those where agriculture and ranching have decimated the forests (Santos-Leal, 2006). In coconut plantations (Cocos nucifera) where the terrain is cleared of other plants, it has been reported that bee richness is low apparently due to reduced nest site availability and foraging resources limited to only this plant species (Meléndez et al., 2004). In Rio Grande do Sul, the extreme south of Brazil, Melipona bicolor schencki is threatened (Blochtein and Marques, 2003), mainly due to the intense deforestation and increasing plantation of Pinus for paper production. These bees need large trees for nesting (Witter et al., 2008) and an undisturbed landscape. Meanwhile, in Ceará, the Northeastern part of Brazil, Melipona quinquefasciata, a groundnesting stingless bee, is endangered due to firewood gathering and agricultural expansion which destroy the ecosystem needed for them to nest as well as their floral host plants (LimaVerde and Freitas, 2002; Eardley et al., 2006).

There are no precise or reliable figures of how much land has been converted annually into agriculture. In Brazil, for instance, an increment of between 1.2 to $2.7 \%$ in cropped area to 2009 is expected, adding an additional 544 to 1276 thousand hectares to the 47.31 million hectares cultivated in 2008 (Conab, 2008). However, it is not possible to estimate what percentage of this area will be from new clearings.

Ironically, most plant species cultivated by man are dependent to some extent on biotic pollinators, from which bees are the most important group (Klein et al., 2007). Many crops could be susceptible to declines in pollinator abundance and diversity of wild pollinators and increasingly frequent collapses of managed honey bee (Apis mellifera) populations (Aizen et al., 2008b). Nevertheless, few empirical data are available for the Neotropics.
In Argentina, Chacoff and Aizen (2006) determined whether forest patches of Yungas (NW Argentina) act as a source of pollinators for grapefruit (Citrus paradisi); they registered a total of 50 insect species on grapefruit flowers, including $22(44 \%)$ species from six families of bees (Apidae, Andrenidae, Anthophoridae, Chrysididae, Halictidae and Megachilidae). The feral Africanized honeybee A. mellifera contributed more than $90 \%$ of the visits to grapefruit flowers, representing the main pollinator, probably because of its capability to persist in agricultural landscapes (Chacoff and Aizen, 2006). Interestedly, the frequency of visits to grapefruit flowers decreased by more than twofold as distance to the forest increased and the flower-visiting fauna became reduced. Chacoff and Aizen (2006) concluded that negative forest edge effects on flowervisiting insects inside grapefruit plantations are widespread in the increasingly deforested landscape of NW Argentina.

Two studies of passion fruit (Passiflora edulis cf. flavicarpa) pollination carried out in NE (Freitas and Oliveira-Filho, 2001) and SE (Camillo, 1996) Brazil found increments from 92 to $700 \%$ after the introduction of 25 Xylocopa frontalis nest/ha. Comparisons between these two studies made by Freitas and Oliveira-Filho (2003) suggest that the number of wild $X$. frontalis in the southern area was much lower than that of the northern area, mainly due to the lack of appropriate nest sites in the highly agricultural landscape of SE Brazil.

Intensive agriculture and ranching implies a collateral use of agrochemicals to reach desirable $\mathrm{pH}$ and amounts of nutrient in the soil as well as the use of chemicals for pest and disease control leading to soil degradation and accumulation of harmful levels of toxic substances which may affect the survival of bees (Ramalho et al., 2000; Caldas and Sousa, 2000). Pesticides are widely used in the Neotropics. In Mexico, Central America and some countries of South America, strict control on the use of many chemicals, including several banned in Europe and the United States, is lacking. Agriculture in Latin America relies heavily on pesticide imports and countries like Mexico, 
Argentina and Brazil are large pesticide importers (Tansey, 1995; Pinheiro and Freitas, unpubl. data). Some pesticides banned somewhere else are still permitted in Mexico, for example, DDT, aldrin, clordane, and clorobenzolate (Alvarado-Mejia et al., 1994). The situation in Central America is similar. In Costa Rica and Nicaragua, extensive use of very hazardous pesticides continues and so does poisoning of bees with organophosphates, carbamates, endosulfan and paraquat. However, in 2000, the ministers of health of the seven Central American countries agreed to ban or restrict twelve pesticides (Wesseling et al., 2005). In Brazil, there are restrictions and regulations to the use of agrochemicals, but little enforcement.

Insecticides are potentially the most damaging agrochemicals for bees (De La Rúa et al., 2009). Although their immediate lethal effects are usually pointed out as the major problem to bees, in many cases sub-lethal effects are more dangerous. They do not cause a prompt death of the bee or (for social species) colony but affect their sensory and neuromotor skills. Pesticides may be applied directly or consumed in food, disrupting sensory, navigational and kin recognition abilities. Sublethal effects can be difficult to notice and impact more on bee diversity or population levels than easily detectable lethal effects (Freitas and Pinheiro, unpubl. data). For example, many insecticides are absorbed by pollen grain lipids and can intoxicate brood of solitary bees or cause brood and young bee mortality for a long time in colonies of social bees (Loper and Ross, 1982).

The effect of pesticides on bee populations has not been documented in South America, but in Mexico and Central America some social bees are currently under threat such as Melipona beecheii (Kerr, 2002) and Bombus medius (González-Acereto, unpubl. data). Although several poisoning incidents are reported in colonies of A. mellifera annually, no direct link with the use of pesticides has been established. However, recently a study in Yucatan found that permethrine at doses used for control of mosquitoes during the rainy season is highly poisonous for honey bees and stingless bees (Valdovinos-Núñez et al.,
2003). Two separate surveys of bee species visiting cultivars of Cucumis moschata and Capsicum chinense in Yucatán showed that the use of pesticides reduced the number of species and the total numbers of individuals after spraying with malathion and diazinon (Xiu Ancona, 2007).

\subsection{Exotic species}

Deliberate or accidental introduction of exotic bee species or other organisms that might interact directly or indirectly with local population can be hazardous to a native bee fauna (reviewed in Stout and Morales, 2009).

The classic example of an exotic animal introduced to the Americas is the case of Apis mellifera. European races of this species, native to the Old World, have been brought to various countries of the Americas by European settlers since the XVI century. In 1956, A. mellifera scutellata, an African race, was introduced to Brazil and spread wildly throughout the continent from Argentina to the USA, except Chile, in what has been called "Africanization" (Seeley, 1986; Winston, 1987).

The introduction of $A$. mellifera to the New World has had a positive social impact through honey hunting and beekeeping; México, Argentina and Brazil are ranked among the greatest honey producers in the world (Freitas et al., 2007). In Mexico, the world's third largest honey producer, Apis mellifera colonies reach some of the highest densities anywhere in the world, in particular in the tropical areas of the Gulf Coast and the Yucatan Peninsula. Moreover, since the 1980s, the numbers of honey bee colonies in tropical Mexico and Central America have probably increased at least two fold due to the colonization of feral colonies of Africanized bees (Roubik, 1989; QuezadaEuán and May-Itza, 2001). Similar patterns are also observed in parts of South America. Also, Apis mellifera may have contributed as pollinator to increase some production of some crops in the Americas, as shown by Freitas and Paxton (1998) and Roubik (2002) to cashew and coffee, respectively.

Large populations of A. mellifera may also be socially impacting stingless beekeeping. In 
NE Brazil reductions in the number of stingless bee beekeepers and colonies in the 1970's and 1980's have been attributed to honeybees. The decrease of stingless beekeeping with Melipona beecheii in the Yucatan peninsula has also been attributed to Africanized bees, although no negative influence is reported by stingless beekeepers of Veracruz along the Mexican Gulf Coast who cultivate Scaptotrigona pectoralis (Quezada-Euán, 2005).

The effect of such numbers of honey bees on the native apifauna and flora is not known. There has been much discussion of the potential negative effects caused by A. mellifera on local populations of native bee species by competition for floral resources and by occupation of nesting sites of highly social stingless bees by honey bees (Roubik, 1989; Freitas et al., 2007; reviewed in Stout and Morales, 2009).

Monitoring pollinator visitation in French Guiana over a period of 17 years, at a site where urban expansion brought some disturbance, Roubik (1996) pointed out a $100 \%$ increase in the proportion of honeybees visits to flowers, whereas native bees visits per flower diminished proportionally to honeybees dominance in forest plots.

Roubik (2000) also noted that a generalist species as the Africanized honeybee, which demands huge resources supply will not always invade all types of ecosystem. He did not find any Africanized honeybee in a preserved area of lowland forest in Ecuador, meaning that different communities are not equally vulnerable to invasion.

Negative interactions of $A$. mellifera with solitary bees are less documented but do also exist (Murray et al., 2009; Stout and Morales, 2009), like the displacement of solitary bees such as Peponapis limitaris and Partamona bilineata from floral resources (Pinkus-Rendon et al., 2005) and honey bees removing all pollen available in passion fruit flowers, preventing pollen harvesting by Xylocopa bees (Freitas and Oliveira-Filho, 2001).

Apart from honey bees, exotic bumblebees seem to be the major concern nowadays in the Neotropics. Pollination in greenhouses has considerably increased in Mexico (Palma et al., 2008a,b), but the two species of bumble bees that had been used for pollination are non-native to Mexico and Central America: Bombus impatiens and Bombus terrestris (Winter et al., 2006; Palma et al., 2008a, b). They began to be imported in 1994 (Velthuis and Van Doorn, 2006) but shipments of European B. terrestris were banned into Mexico between 1995 and 1996 due to parasite infections (Winter et al., 2006). However, colonies of North American B. impatiens are still allowed into Mexico and Guatemala (Morales, 2007). Therefore, there is a potential risk of naturalization of exotic bumble bees, as has already occurred in other countries worldwide (Colla et al., 2006). This is a serious threat to native bumble bees that can be infected with diseases and parasites and hybridized to an unknown extent with their foreign counterparts (CuadrielloAguilar and Salinas-Navarrete, 2006; Velthuis and van Doorn, 2006; reviewed in Stout and Morales, 2009).

In temperate forests of the southern Andes of Argentina, the native Bombus dahlbomii declined while foragers of the exotic European Bombus ruderatus (introduced via New Zealand) increased along a gradient of anthropogenic habitat alteration (Morales and Aizen, 2002; Aizen and Feinsinger, 2003; Morales, 2007). A second invader, Bombus terrestris, was recently registered for this biogeographic region, probably coming from Chile where it was introduced for pollination purposes (Torreta et al., 2006). There are concerns of its spread towards Uruguay, Paraguay, Bolivia and southern Brazil. Exotic pollinators can modify basic quantitative parameters of plant-pollinator webs, such as the strength of interactions, influencing the basic foundations of the architecture of mutualistic networks (Aizen et al., 2008a) with putative consequences for the preservation of plant and animal populations (Stout and Morales, 2009).

\subsection{Other threats}

Heavy metals are chemical elements of relative density higher than $5 \mathrm{~g} / \mathrm{cm}^{3}$ found in high concentrations in waste areas (biosolids and mining) or places of intense use (industrial 
byproducts and agrochemicals) (Carneiro et al., 2001). Some of these elements, like cadmium $(\mathrm{Cd})$, lead $(\mathrm{Pb})$ and mercury $(\mathrm{Hg})$, once in the soil can retard plant growth, affect soil microorganisms and interfere with the ecosystem functions (Baker et al., 1994). There have been reports of high levels of heavy metals in honey, royal jelly and the bodies of honey bee workers elsewhere, but investigations in this area are just starting in Latin America (Toporcak et al., 1992; Leita et al., 1996). These studies are needed because Mexico and most countries of Central and South America are under a fast pace of industrialization, generating more and more heavy metal residues that can become a problem for terrestrial and aquatic ecosystems in the region (Accioly et al., 2000).

Finally, droughts, floods, large-scale bushfires and hurricanes are becoming more frequent and intense throughout the Neotropics, maybe as a product of world climate changes. These perturbations could have unpredictable effects on the flora (species abundance, distribution and phenology) and, as consequence, on the bee fauna. As far as we know, empirical testing these kinds of effects on native bees has not been undertaken in the Neotropics, ignoring the vulnerability of many native bees to human impacts and climate change.

\section{CONSERVATION}

Although there is an overall agreement that many bee species in the Neotropics are at some degree of risk, well documented cases are rare. In fact, long-term studies performed in intact forests for two decades in French Guiana and Panama showed no decline in native bee abundance (Roubik, 1996, 2000; Roubik and Wolda 2001). As Roubik (2000) pointed out it is more likely the occurrence of temporary ecological replacement of one visitor by another than regional extinction or geographical decline.

The understanding of conservation problems is linked to the knowledge of extinction, survival and colonizing rates. Slaa (2006) found in a pioneer study on population dynamics in Costa Rica that most stingless bee species presented an estimated colony life span of 23.3 years in both forested and deforested areas where the research was made, meaning that they could swarm only once each 20 years to maintain their populations. This kind of results could give support to colony management and to better practices of bee conservation.

The main problem faced in Latin America is the lack of information on richness, diversity, taxonomy, distribution, population dynamics and impact of man activities on most bee species. This, associated with local beliefs, which do not always correspond to the truth, has made difficult efforts to bee conservation in Latin America. Moreover, the lack of public awareness on the role of bees to agriculture and ecosystem health makes difficult support (political and monetary) to more comprehensive projects. Therefore, any efforts towards the conservation of Neotropical bees will need to fill this knowledge gap existing about the subject species, attract public interest and input an economic or ecological value to the bee. The most obvious use to bees that could both be of economic and ecological interest and also attract public concern is plant pollination, either in wild or agroecosystems (Freitas and Pereira, 2004). However, much study ought to be carried out on most plant species to determine their potential pollinators, pollinator efficiency, rearing and management.

The proposal by the Brazilian government for an International Pollinator Initiative (IPI) as a global issue for the Convention of the Biological Diversity (Dias et al., 1999; Byrne and Fitzpatrick, 2009) tackled these points. It was important to call the attention to pollinators as a whole and bees in particular. It has influenced recent Brazilian bee research development and may have contributed in a similar fashion to other countries of the region.

The IPI gave the framework for planning and developing regional actions like the Brazilian Initiative of Pollinators. It arose as a potent forum allowing communication with other regional efforts as well as organizing the information on bees in the country. The support given by the Ministry of Environment for pollination projects, the global meetings that occurred in Brazil or elsewhere with the 
participation of Brazilian leadership and the focus on ecosystem services provided by the bees improved the new approaches for national bee science. Initially, a survey on the knowledge related to Brazilian bees, their occurrence sites, collections, taxonomic status and checklists were done, helped by the global bioinformatics and databases. Awareness by the scientific community and capacity building came with international pollination courses and scientific meetings with other global initiatives (Imperatriz-Fonseca et al., 2006, 2007, 2008).

Initiatives like the IPI are proving to be a powerful tool to enlighten and involve government, public and researchers in coordinated efforts to acquire much needed knowledge on the aspects pointed out above and to contribute to mitigating the negative impact of the threatening activities listed and discussed here (reviewed in Byrne and Fitzpatrick, 2009).

Mexico, which takes part in the North American Pollinator Protection Campaign, is now considering to create its own initiative or a joint initiative with Central American countries due to their bee fauna's peculiarities. Colombia and Argentina have discussed to follow the same example.

\section{CONCLUSIONS}

The Neotropics bee fauna is rich and diverse, but little studied. Deforestation, agriculture intensification and introduction/spread of exotic competing bee species are considered the main threats to most indigenous species, but there are not enough reliable data to support further conclusions. Other less obvious causes can affect the populations of some bee species. The main problem faced in Latin America to conserve the native bee fauna is the lack of information on richness, diversity, taxonomy, distribution, population dynamics and impact of man activities on most bee species, associated to local believes, not always corresponding to the truth. Efforts to conserve the native bee fauna include better knowledge of bee richness and diversity (standardized surveys, larger bee collections and appropriate identification of bee species) and of their population dynamics, raising of public and policy makers' awareness, commercial applications of bee products and services such as pollination and preservation of natural habitat. Pollination initiatives like the International Pollinators Initiative and the Brazilian Pollinators Initiative are proving to be a powerful tool to enlighten and involve government, public and researchers in coordinated efforts to acquire much needed knowledge on important issues and to contribute to mitigating the negative impact of the threatening activities to bees in the Latin America.

\section{ACKNOWLEDGEMENTS}

We thank the valuable suggestions of two anonymous referees, Robert Paxton and Mark Brown for their editorial work, and Isac G.A. Bomfim for help in preparing the manuscript. We are also thankful to Fapesp (04/15801-0) and CNPq (484587/2007-2).

Diversité, statut de conservation et menaces concernant les abeilles indigènes dans les régions néotropicales.

Apoidea / abeille / biodiversité / Amérique centrale / Amérique du Sud / protection / taxonomie

Zusammenfassung - Diversität, Bedrohung und Schutz einheimischer Bienen in den Neotropen. Die vorliegende Arbeit soll einen Überblick geben über die Diversität und den Artenreichtum der neotropischen Bienenfauna, die Bedrohungen, denen sie ausgesetzt ist, als auch eine Darstellung der Initiativen und Probleme im Artenschutz der einheimischen Bienen. Die Daten beruhen auf umfassenden Literaturrecherchen. Diese Informationen wurden dann von den Autoren diskutiert und in Form relevanter Punkte inhaltlich zusammengefasst. Das Ergebnis zeigt, dass die Neotropis eine artenreiche Bienenfauna aufweist und dass diese sogar unterschätzt wird. Den existierenden 5000 gültigen Artennamen stehen Schätzungen gegenüber, dass diese weniger als ein Drittel der tatsächlich vorkommenden Arten umfassen (Tab. I). Bedrohungen, denen einheimische Bienen der Neotropis ausgesetzt sind, liegen vor allem menschliche Aktivitäten zugrunde, die in drei Kategorien zusammengefasst werden können: Entwaldung, Intensivierung der Landwirtschaft und Einführung fremder Arten. Die Hauptursachen der Entwaldung sind Holzeinschlag, das Sammeln von Feuerholz, die Produktion von Holzkohle und Rodungen zur Schaffung von landwirtschaftlichen und Weideflächen. Der Amazonasregenwald, Mexiko und Zentralamerika 
weisen die höchsten Entwaldungsraten in Amerika auf, aber auch in den Chaco-Wälder der argentinischen und kolumbianischen Anden schreitet die Entwaldung fort (Tab. II). Die Ausbreitung und Intensivierung der Landwirtschaft wird vielfach als die wichtigste Bedrohung für Bienenarten angesehen. Sie führt zu einer Verringerung der Artendiversität bei Tieren und Pflanzen, verringert das Angebot an Nistmöglichkeiten und Futterquellen, und durch das Ausbringen von Pestiziden und Pflügen der Böden werden sowohl Bienenlarven als auch Adulte getötet. Ironischerweise sind die meisten Kulturpflanzen mehr oder weniger stark auf die Präsenz biotischer Bestäuber angewiesen, wobei die Bienen die wichtigste Gruppe darstellen. Auch die Einführung fremder Bienenarten und anderer exotischer Organismen, die mit der lokalen Bienenfauna in Wechselwirkung treten, kann die einheimische Bienenfauna beeinträchtigen. Die Einführung von Apis mellifera in die Neue Welt zur Steigerung der Honigproduktion und die von exotischen Hummelarten für Bestäubungszwecke hat zu Bedenken Anlass gegeben über die Konkurrenz mit einheimischen Bienen um Futter- und Nistmöglichkeiten, sowie zur Ausbreitung von Krankheiten und Parasiten und zur Hybridisierung mit einheimischen Hummmelarten. Anderen Bedrohungen liegen Trockenzeiten, Überschwemmungen, grossflächige Buschbrände, Hurrikane und die Kontaminierung der Ökosysteme mit Schwermetallen zugrunde. Die Hauptprobleme, denen sich Initiativen zum Artenschutz einheimischer Bienen gegenübersehen, sind fehlende Kenntnisse über Artenreichtum, Diversität, Taxonomie, Populationsdynamik und den Einfluss menschlicher Aktivitäten auf die meisten Bienenarten. Um zu besseren Kenntnissen über Artenreichtum, Diversität und Populationsdynamik zu kommen, ist Öffentlichkeitsarbeit und Aufklärung bei Politikverantwortlichen erforderlich. Hierin können die Kommerzialisierung von Bienenprodukten, sowie Aufklärung über die Bedeutung von Bestäubern und der Schutz natürlicher Habitate eine wichtige Rolle spielen. Bestäuberinitiativen erweisen sich hierbei als wichtige Werkzeuge, um Politiker, die Öffenlichkeit und Forscher in koordinierter Weise zusammenzubringen, Wissen über wichtige Fragen zu schaffen und insbesondere die negativen Auswirkungen bienenbedrohender Aktivitäten in Lateinamerika abzumildern.

Apoidea / Bienen-Biodiversität / Zentralamerika / Südamerika / Artenschutz / Taxonomie

\section{REFERENCES}

Accioly A.M.A., Neto A.E.F., Muniz J.A., Faquin V., Guedes G.A.A. (2000) Pó de forno elétrico de siderurgia como fonte de micronutrientes e de contaminante para plantas de milho, Pesq. Agropec. Bras. 35, 1483-1491.

Aizen M.A., Feisinger P. (1994) Habitat fragmentation, native insect pollinators, and feral honeybees in Argentine "chaco serrano", Ecol. Appl. 4, 378392.

Aizen M.A., Feisinger P. (2003) Bees not to be? Responses of insect pollinator faunas and flower pollination to habitat fragmentation, in: Bradshaw G.A., Marquet P.A. (Eds.), How landscapes change: Human disturbance and ecosystem disruptions in the Americas, Springer-Verlag. Berlin, pp. 111-129.

Aizen M.A., Morales C.L., Morales J.M. (2008a) Invasive mutualists erode native pollination webs, PLOS Biol. 6, 396-403.

Aizen M.A., Garibaldi L.A., Cunningham S.A., Klein A.M. (2008b) Long-term global trends in crop yield and production reveal no current pollination shortage but increasing pollinator dependency, Curr. Biol. 18, 1572-1575.

Alvarado-Mejia J., Cobos-Gasca V., GonzalezNavarrete L. (1994) Insecticidas y herbicidas de mayor uso en los horticultores de Yucatán: implicaciones a la salud y al ambiente, Rev. Biomed. 5, 180-190.

Alves-dos-Santos I. (2005) Nota Técnica: A Importância de Coleções de Abelhas e dos Checklists para a Iniciativa Internacional de Polinizadores (versão 03/06/05). [online] http:// www.cria.org.br/cgee/col (access on 23 January 2009).

Alves-dos-Santos I., Kleinert A.M.P. (2007) Quando um visitante floral é um polinizador? Ann. VIII Congr. de Ecologia do Brasil. Caxambu (MG), CDRom.

Amat G.G., Gonzalo Andrade M., Amat E.G. (Eds.) (2007) Libro Rojo de los Invertebrados Terrestres de Colombia - Bogotá-Instituto de Ciencias Naturales-Universidad Nacional de Colombia, Conservaciòn Internacional Colombia, Instituto Alexander von Humboldt, Ministerio de Ambiente, Vivienda y Desarrollo Territorial, pp. $155-179$.

Ayala R. (2006) Bee diversity in Mexico, in: Kevan P., Imperatriz-Fonseca V.L. (Eds.), Pollinating bees the conservation link between agriculture and nature, Ministry of Environment, Brasilia.

Ayala R., Griswold T., Bullock S.H. (1993) The native bees of Mexico, in: Ramamoorthy T.P., Bye R., Lot A., Fa J. (Eds.), Biological diversity of Mexico origins and distribution, Oxford University Press, UK.

Ayala R., Griswold T., Yanega D. (1996) Apoidea (Hymenoptera), in: Llorente J., Garcia-Aldrete A.N., González-Soriano E. (Eds.), Biodiversidad, taxonomia y biogeografia de artrópodos mexicanos: hacia una síntesis de su conocimiento, 
IBUNAM/UNAM/CONABIO, México, pp. 423464.

Baker A.J.M., McGrath S.P., Sodoli C.M.D., Reeves R.D. (1994) The possibility of in situ heavy metal decontamination of polluted soils using crops of metalaccumulating plants, Res. Conserv. Recycling. 11, 41-49.

Biesmeijer J.C., Slaa E.J. (2006) The structure of eusocial bee assemblages in Brazil, Apidologie 37, 240-258.

Biesmeijer J.C., Slaa E.J., Castro M.S., Viana B.F., Kleinert A.M.P., Imperatriz-Fonseca V.L. (2005) Connectance of Brazilian social bee-food plant networks is influenced by habitat, but not latitude, altitude or network size, Biota Neotrop. 5, 1-10.

Blochtein B., Marques B.H. (2003) Himenópteros, in: Fontana C.S., Glayson A.B., Reis R.B. (Eds.), Livro vermelho da fauna ameaçada de extinção no Rio Grande do Sul. EDIPUCRS, Porto Alegre, pp. $95-109$.

Bonilla-Gómez M.A. (2007) Fichas de categorización Euglossini, in: Libro Rojo de los Invertebrados Terrestres de Colombia, in: Amat G.G., Gonzalo Andrade M., Eduardo Amat G. (Eds.), Bogotá-Instituto de Ciencias NaturalesUniversidad Nacional de Colombia, conservación Internacional Colombia, Instituto Alexander von Humboldt, Ministerio de Ambiente, Vivienda y Desarrollo Territorial, pp. 155-179.

Byrne A., Fitzpatrick U. (2009) Bee conservation policy at the global, regional and national levels, Apidologie 40, 194-210.

Caldas E.D., Souza L.C.K.R. (2000) Chronic dietary risk assessment for pesticide residues in Brazilian food, Rev. Saúde Pública 34, 5.

Camargo J.M.F., Pedro S.R.M. (2007) Meliponini Lepeletier, 1836, in: Moure J.S., Urban D., Melo G.A.R. (Eds.), Catalogue of bees (Hymenoptera, Apoidea) in the Neotropical Region, Curitiba, Sociedade Brasileira de Entomologia, pp. 272578.

Camillo E. (1996) Utilização de espécies de Xylocopa (Hymenoptera, Anthophoridae) na polinização do maracujá amarelo, in: Encontro Sobre Abelhas, 2., 1996, Ribeirão Preto, Anais, Ribeirão Preto: Universidade de São Paulo, Faculdade de Filosofia Ciências e Letras de Ribeirão Preto, pp. 141-146.

Carneiro M.A.C., Siqueira J.O., Moreira F.M.S. (2001) Estabelecimento de plantas herbáceas em solo com contaminação de metais pesados e inoculação de fungos micorrízicos arbusculares, Pesq. Agropec. Bras. 36, 1443-1452.

Chacoff N., Aizen M.A. (2006) Edge effects on flowervisiting insects in grapefruit plantations bordering premontane subtropical forest, J. Appl. Ecol. 43, $18-27$.

Colla S.R., Otterstatter M.C., Gegear R.J., Thomson J.D. (2006) Plight of the bumblebee: Pathogen spillover from commercial to wild populations, Biol. Conserv. 129, 461-467.

Conab (2008) Acompanhamento da safra brasileira. Safra 2008/2009. [online] http://www.conab.gov. br/conabweb/download/safra/1graos_08.09.pdf (accessed 23 January 2009).

Contreras-Acosta H.H. (1998) Abejas nativas (Hymenoptera:Apoidea; Serie: Apiformes) de la reserva especial de la Biósfera de Ria Lagartos, Yucatán, México, B Sc. Thesis Universidad Autónoma de Yucatán, México.

Cuadriello-Aguilar J.I., Salinas-Navarrete J.C. (2006) Los riesgos de importar polinizadores exóticos y la importancia de su legislación. Primer Taller de Polinizadores en México (NAPPC), 20-22 de Noviembre, San Juan del Rio Queretaro.

De La Rúa P., Jaffé R., Dall’Olio R., Muñoz I., Serrano J. (2009) Biodiversity, conservation and current threats to European honeybees, Apidologie 40, 263-284.

Dias B.F.S., Raw A., Imperatriz-Fonseca V.L. (1999) São Paulo Declaration on Pollinators. [online] http://www.biodiv.org/doc/ref/agr-pollinator-rpt. pdf (accessed 23 January 2009).

Enriquez E., Yurrita C.L., Ayala R., Monroy C., Marroquin Y.A. (2003) Listado preliminar de las abejas sin aguijón de Guatemala. III Seminario Mesoamericano sobre abejas sin aguijón, Tapachula, México.

Eardley C., Roth D., Clarke J., Buchmann S., Gemmil B. (2006) Pollinators and pollination: a resource book for policy and practice, African Pollinator Initiative, Pretoria.

FAO (Food and Agriculture Organization of the U.N.) (2003) The State of the World's Forests 2003. FAO, Rome.

Fearnside P.M. (2008) The roles and movements of actors in the deforestation of Brazilian Amazonia, Ecol. Soc. 13, 23.

Freitas B.M., Paxton R.J. (1998) A comparison of two pollinators: the introduced honeybee (Apis mellifera) and a indigenous bee (Centris tarsata) on cashew (Anacardium occidentale L.) in its native range of NE Brazil, J. Appl. Ecol. 35, 109-121.

Freitas B.M., Oliveira-Filho J.H. (2001) Criação racional de mamangavas para polinização em áreas agrícolas, BNB, Fortaleza.

Freitas B.M., Oliveira-Filho J.H. (2003) Ninhos racionais para mamangava (Xylocopa frontalis) na polinização do maracujá-amarelo (Passiflora edulis), Ciência Rural 33, 1135-1139.

Freitas B.M., Pereira J.O.P. (2004) Solitary bees: conservation, rearing and management for pollination, Imprensa Universitária UFC, Fortaleza.

Freitas B.M., Sousa R.M., Bomfim I.G.A. (2007) Absconding and migratory behaviors of feral Africanized honey bee (Apis mellifera L.) colonies 
in NE Brazil, Acta Sci. Biol. Sci. 29, 381-385.

Galetto L., Aguilar R., Musicante M., Astegiano J., Ferreras A., Jausoro M., Torres C., Ashworth L., Eynard C. (2007) Fragmentación de hábitat, riqueza de polinizadores y reproducción de plantas nativas en el Bosque Chaqueño de Córdoba, Argentina, Ecol. Austral. 17, 67-80.

Gomez-Pompa A., Kaus A. (1999) From pre-Hispanic to future conservation alternatives: lessons from Mexico, Proc. Natl. Acad. Sci. USA 96, 59825986.

González V.H., Nates-Parra G. (1999) Sinopsis de Parapartamona (Hymenoptera: Apidae: Meliponini) un género estrictamente Andino, Rev. Acad. Colomb. Cienc. Exactas, Fisicas y Naturales (suplemento especial) 23, 171-180.

Goudie A.S. (Ed.) (2001) Encyclopedia of Global Change, Oxford University Press.

Grau H.R., Aide T.M., Gaspari N.I. (2005) Globalization and soybean expansion into semiarid ecosystems of Argentina, AMBIO 34, 265-266.

Imperatriz-Fonseca V.L., Saraiva A.M., De Jong D. (2006) Bees as Pollinators in Brazil: assessing the status and suggesting the best practices, Holos Ed., Ribeirão Preto.

Imperatriz-Fonseca V.L., Saraiva A.M., Gonçalves L.S. (2007) A Iniciativa Brasileira de Polinizadores e os avanços para a compreensão do papel dos polinizadores como produtores de serviços ambientais, Biosci. J., Uberlandia 23, 100-106.

Imperatriz-Fonseca V.L., Alves D.A., Saraiva A.M. (2008) The history and advances in the S. Paulo Declaration on Pollinators: he experience of Brazil in native bees, in: Ans of V Congreso Mesoamericano sobre abejas sin aguijón, pp. 142147.

INPE (2008) [online] http://www.inpe.br/noticias/ noticia.php?Cod_Noticia $=1597$ (accessed 23 January 2009).

Jamhour J., Laroca S. (2004) Uma comunidade de abelhas silvestres (Hym., Apoidea) de Pato Branco (PR-Brasil): diversidade, fenologia, recursos florais e aspectos biogeográficos, Acta Biol. Paranaense 33, 97-119.

Kerr W.E. (2002) Extincao de especies: a grande crise biologica do momento e como afeta os meliponineos. Anais do V encontro sobre abelhas, 2002, Ribeirão Preto, SP Brasil, pp. 4-9.

Klein A.M., Vaissière B.E., Cane J.H., SteffanDewenter I., Cunningham S.A., Kremen C., Tscharntke T. (2007) Importance of pollinators in changing landscapes for world crops, Proc. R. Soc. London B, Biol. Sci. 274, 303-313.
Kremen C., Williams N.M., Thorp R.W. (2002) Crop pollination from native bees at risk from agricultural intensification, Proc. Natl. Acad. Sci. USA 99, 16812-16816.

Kremen C., Williams N.M., Bugg R.L., Fay J.P., Thorp R.W. (2004) The area requirements of an ecosystem service: crop pollination by native bee communities in California, Ecol. Lett. 7, 1109-1119.

Leita L., Muhlbachova G., Cesco S., Barbatini R., Mondini C. (1996) Investigation of the use of the honey bee and honey products to asses heavy metals contamination, Environ. Mon. Assess. 43, 1-9.

Lima-Verde L.W., Freitas B.M. (2002) Occurrence and biogeographic aspects of Melipona quinquefasciata in NE Brazil (Hymenoptera, Apidae), Braz. J. Biol. 62, 479-486.

Loper G.M., Ross B.H. (1982) Concentration of Methyl parathion from Penncap-M in pollens of various lipid and oil contents, Environ. Entomol. 11, 925-927.

Maes J.M. (1993) Catálogo de los Apoidea (Hymenoptera) de Nicaragua, Rev. Nicar. Entomol. 26, 11-30.

Meléndez V., Parra-Tabla V., Kevan P.G., RamirezMorillo I., Harries H., Fernandez-Barrera M., Zizumbo-Villareal D. (2004) Mixed mating strategies and pollination by insects and wind in coconut palm (Cocos nucifera L. (Arecaceae)), Agric. Forest Entomol. 6, 155-163.

Morales C.L. (2007) Introducción de abejorros (Bombus) no nativos: causas, consecuencias ecológicas y perspectivas, Ecol. Austral. 17, 51-65.

Morales C.L., Aizen M.A. (2002) Does invasion of exotic plants promote invasion of exotic flower visitors? A case study from the temperate forests of the southern Andes, Biol. Invasions 4, 87-100.

Morton D.C., DeFries R.S., Shimabukuro Y.Y., Anderson L.O., Aai E., del Bon Espirito-Santo F., Freitas R., Morisette J. (2006) Cropland expansion changes deforestation dynamics in the Southern Brazilian Amazon, Proc. Natl. Acad. Sci. USA 102, 14637-14641.

Moure J.M., Urban D., Melo G.A.R. (2007) Catalogue of bees (Hymenoptera, Apoidea) in the Neotropical Region, Curitiba, Sociedade Brasileira de Entomologia.

Murray T.E., Kuhlmann M., Potts S.G. (2009) Conservation ecology of bees: populations species and communities, Apidologie 40, 211-236.

Nates-Parra G. (2005) Abejas corbiculadas de Colombia (Hymenoptera: Apidae). Unibiblos, Universidad Nacional de Colombia, Bogotá, Colombia.

Nates-Parra G. (2007) Fichas de categorización Meliponini En : Libro Rojo de los Invertebrados Terrestres de Colombia, Amat G.G., Gonzalo Andrade M., Eduardo Amat G. (Eds.), 
Bogotá, Instituto de Ciencias Naturales, Universidad Nacional de Colombia, Conservaciòn Internacional Colombia, Instituto Alexander von Humboldt, Ministerio de Ambiente, Vivienda y Desarrollo Territorial, pp. 144-154.

Oldroyd B.P., Nanork P. (2009) Conservation of Asian Honey bees, Apidologie 40, 296-312.

Palma G., Quezada-Euán J.J.G., Reyes-Oregel V., Meléndez V., Moo-Valle H. (2008a) Production of greenhouse tomatoes (Lycopersicon esculentum) using Nannotrigona perilampoides, Bombus impatiens and mechanical vibration (Hym.: Apoidea), J. Appl. Entomol. 132, 79-85.

Palma G., Quezada-Euán J.J.G., Meléndez V., Irigoyen J., Valdovinos-Nuñez G.R., Rejón M. (2008b) Comparative efficiency of Nannotrigona perilampoides, Bombus impatiens (Hymenoptera: Apoidea), and mechanical vibration on fruit production of enclosed habanero pepper, J. Econ. Entomol. 101, 132-138.

Pinheiro-Machado C., Alves dos Santos I., ImperatrizFonseca V.L., Kleinert A.M.P., Silveira F.A. (2002) Brazilian bee surveys: state of knowledge, conservation and sustainable use, in: Kevan P., Imperatriz Fonseca V.L. (Eds.), Pollinating Bees, The Conservation Link Between Agriculture and Nature, Ministério do Meio Ambiente, Brasília, pp. 115-129.

Pinkus-Rendon M.A., Parra-Tabla V., MeléndezRamírez V. (2005) Floral resource use and interactions between Apis mellifera and native bees in cucurbit crops in Yucatán, México, Can. Entomol. 137, 441-449.

Quezada-Euán J.J.G. (2005) Biología y uso de las abejas sin aguijón de la Península de Yucatán, México (Hymenoptera: Meliponini), Ediciones UADY, México, 102 p.

Quezada-Euán J.J.G., May-Itza W. de J. (2001) Partial seasonal isolation of African and Europeanderived Apis mellifera (Hymenoptera:Apidae) drones at congregation areas from subtropical Mexico, Ann. Entomol. Soc. Am. 94, 540-544.

Ramalho J.F.G.P., Amaral Sobrinho N.M.B., Velloso A.C.X. (2000) Contaminação da microbacia de Caetés com metais pesados pelo uso de agroquímicos, Pesq. Agropec. Bras. 35, 1289-1303.

Roubik D.W. (1989) Ecology and natural history of tropical bees, Cambridge University Press, New York.

Roubik D.W. (1996) African honey bees as exotic pollinators in French Guiana, in: Matheson A., Buchman S.L., O'toole C., Westrich P., Williams I.H. (Eds.), The conservation of bees, Academic Press, London, pp. 163-171.

Roubik D.W. (2000) Pollination system stability in Tropical America, Conserv. Biol. 14, 1235-1236.
Roubik D.W. (2002) The value of bees to the coffee harvest, Nature 417, 708 .

Roubik D.W., Wolda H. (2001) Do competing honey bees matter? Dynamics and abundance of native bees before and after honey bee invasion, Popul. Ecol. 43, 53-62.

Roubik D.W., Villanueva R., Cabrera E.F., Colli Ucan W. (1991) Abejas nativas de la reserva de la biósfera de Sian Ka'an, Quintana Roo, Mexico, in: Navarro L., Robinson J.G. (Eds.), Diversidad Biológica en la Reserva de la Biósfera de Sian Ka’an, Quintana Roo, México, pp. 317-320.

Santos-Leal A. (2006) Distribución espacial de los sitios de anidación de abejas eusociales (Hymenoptera-Apidae: Meliponini y Apini) en Sudzal, Yucatán, México, M Sc. Thesis Universidad Autónoma de Yucatán, México.

Seeley T.D. (1986) Honeybee Ecology. A study of Adaptation in Social Life, Princeton, University Press, Princeton, New Jersey.

Silveira F.A. (2004) Monitoring pollinating wild bees, in: Freitas B.M., Pereira J.O.P. (Eds.), Solitary bees: conservation, rearing and management for pollination, Imprensa Universitária UFC, Fortaleza.

Silveira F.A., Campos M.J.O. (1995) A melissofauna de Corumbataí (SP) e Paraobeba (MG): uma análise da biogeografia das abelhas do cerrado brasileiro (Hymenoptera: Apoidea), Rev. Bras. Entomol. 39, 371-401.

Silveira F.A., Melo G.A.R., Almeida E.A.B. (2002) Abelhas Brasileiras - Sistemática de Identificação, Belo Horizonte.

Silveira F.A., Pinheiro-Machado C., Alves dos Santos I., Kleinert A.M.P., Imperatriz-Fonseca V.L. (2002) Taxonomic constraints for the conservation and sustainable use of wild pollinators - the Brazilian wild bees, in: Kevan P.G., ImperatrizFonseca V.L. (Eds.), Pollinating bees - the conservation link between agriculture and nature, Brasilia, Ministry of Environment, pp. 41-50.

Slaa E.J. (2006) Population dynamics of a stingless bee community in the seasonal dry lowlands of Costa Rica, Insect. Soc. 53, 70-79.

Souza Jr C.M. (2006) Mapping land use of tropical regions from space, Proc. Natl. Acad. Sci. USA 103, 14261-14262.

Stout J.C., Morales C.L. (2009) Ecological impacts of invasive alien species on bees, Apidologie 40, 388-409.

Tansey R. (1995) Eradicating the pesticide problem in Latin America, Business and Society Review, Winter 92, 55-59.

Toporcak J., Legath J., Kulkova J. (1992) Mercury levels in bee and honey samples from industrially 
contaminated and uncontaminated areas, Med. Vet. 37, 405-412.

Torreta J.P., Medan D., Abrahamovich A.H. (2006) First record of the invasive bumblebee Bombus terrestris (L.) (Hymenoptera, Apidae) in Argentina, Trans. Am. Entomol. Soc. 132, 285-289.

Valdovinos-Nuñez G.R., Quezada-Euán J.J.G., Marrufo-Olivares J. (2003) Efecto de la aplicación aérea de permetrina en Apis mellifera y abejas nativas sin aguijón (Hymenoptera: Apidae) en Yucatán, México, XVII Seminario Americano de Apicultura, Aguascalientes, México, pp. 147149.

Velthuis H.H.W., Van Doorn A. (2006) A century of advances in bumblebee domestication and the economic and environmental aspects of its commercialization for pollination, Apidologie 37, 421451.

Wesseling C., Corriols M., Bravo V. (2005) Acute pesticide poisoning and pesticide registration in Central America, Toxicol. Appl. Pharmacol. 207, 697-705.

Winston M.L. (1987) The biology of honey bee. Harvard University Press, Massachusetts, USA.
Winter K., Adams L., Thorp R., Inouye D., Day L., Ascher J., Buchmann S. (2006) Importation of non-native bumble bees into North America: Potential consequences of using Bombus terrestris and other non-native bumble bees for greenhouse crop pollination in Canada, Mexico and the United States. NAPPC Washington, $33 \mathrm{p}$.

Witter S., Lopes L.A., Imperatriz-Fonseca V.L., Blochtein B., Lisboa B.B., Mondin C. (2008) Ninhos de meliponíneos em um campo de altitude do Rio Grande do Sul, in: VIII Encontro sobre Abelhas de Ribeirão Preto, in: CDRom.

WWF (2008) Amazon deforestation. [online] http:// www.panda.org/about_wwf/where_we_work/ latin_america_and_caribbean/region/amazon/ problems/amazon_deforestation/index.cfm. (accessed 23 January 2009).

Xiu-Ancona P. (2007) Diversidad de abejas en cultivos de Capsicum chinense (Jacq.) y evaluación del efecto toxicológico del malatión y diazinón en dos especies de abejas: Nannotrigona perilampoides y Trigona nigra, M Sc. Thesis Universidad Autónoma de Yucatán, México.

Zak M., Cabido M., Hodgson J. (2004) Do subtropical seasonal forests in the Gran Chaco, Argentina, have a future? Biol. Conserv. 120, 589-598. 